Wojciech Grzegorczyk

\title{
Strategie marketingowe polskich przedsiębiorstw na rynkach międzynarodowych
}

\section{Wstęp}

Przedsiębiorstwo, które zamierza wejść na rynki międzynarodowe, powinno postępować racjonalnie, tzn. zgodnie z etapami ekspansji na te rynki. W literaturze podnoszącej problemy marketingu międzynarodowego, w której przedstawione są wyniki badań nad tymi zagadnieniami, dominuje koncepcja, wywodząca się z modelu internacjonalizacji Uniwersytetu w Uppsali. Według niej proces angażowania się przedsiębiorstw w wejście na rynki zagraniczne obejmuje kilka faz i wiąże się ze strategią ich uczenia się i systematycznego zdobywania wiedzy o tych rynkach. Druga koncepcja zakłada, że przedsiębiorstwo wchodząc na rynki zagraniczne może pominąc niektóre fazy, korzystając z doświadczenia innych przedsiębiorstw w swojej branży. Natomiast według kolejnego poglądu, przedsiębiorstwo odchodzi od modelu fazowego i od początku swojego istnienia stara się działać na jak największej liczbie rynków zagranicznych, a w skrajnym przypadku na rynku globalnym. Wybór którejkolwiek z koncepcji ekspansji na rynki międzynarodowe warunkuje stosowanie przez przedsiębiorstwo określonej strategii marketingowej na wybranych rynkach zagranicznych. Przygotowanie trafnej strategii marketingowej, opartej na rzetelnej analizie zasobów przedsiębiorstwa, jego pozycji konkurencyjnej i czynników otoczenia rynków międzynarodowych, na które przedsiębiorstwo zamierza dokonać ekspansji, jest warunkiem koniecznym do osiągnięcia sukcesu na tych rynkach.

\section{Główne założenia strategii ekspansji przedsiębiorstwa na rynki międzynarodowe}

O wyborze jednej ze wspomnianych koncepcji wejścia na rynki międzynarodowe, a także o intensywności ekspansji przedsiębiorstwa na rynki zagraniczne i jego strategii marketingowej decydują czynniki wewnętrzne (endogeniczne) 
charakteryzujące przedsiębiorstwo i czynniki jego otoczenia (egzogeniczne). Do czynników endogenicznych zaliczamy przede wszystkim zasoby przedsiębiorstwa, jego doświadczenie, wiedzę o rynkach zagranicznych oraz pozycję konkurencyjną przedsiębiorstwa. Natomiast do czynników otoczenia zaliczamy czynniki geograficzne, ekonomiczne, demograficzne, prawne i kulturowe, jakie charakteryzują rynki międzynarodowe.

Najczęściej spotykaną formą ekspansji przedsiębiorstw na rynki międzynarodowe jest ekspansja, zgodnie z koncepcją fazowego wejścia na te rynki. Wówczas przedsiębiorstwo musi dokonać oceny i wyboru rynku (rynków) docelowych oraz formy wejścia na nie. W następnej kolejności należy opracować strategię marketingową, która będzie na tych rynkach realizowana ${ }^{1}$.

Ocena rynku zagranicznego dokonywana jest na podstawie informacji o charakteryzujących go zmiennych. Na ich podstawie należy określić atrakcyjność rynku. Najczęściej można to ustalić stosując metodę portfelową. Wykorzystuje się wtedy dla ustalenia tej atrakcyjności wiele różnych czynników, dzięki czemu ocena jest pełna i ograniczony jest subiektywizm badania. Wówczas dokonuje się wyboru tego rynku zagranicznego, którego atrakcyjność uzyskała najwyższy poziom na określonej skali punktów. Można również oceniać poszczególne rynki zagraniczne, wartościując ich atrakcyjność i ryzyko wejścia na nie. Konfrontacja obu tych wartości pozwoli utworzyć macierz dziewięcioelementową o niskim, średnim i wysokim ryzyku oraz niskiej, średniej i wysokiej atrakcyjności rynków. Najkorzystniejszym wariantem jest ten, w którym rynek zagraniczny ma najwyższą atrakcyjność i niewielkie lub średnie ryzyko, najmniej korzystnym natomiast taki, kiedy rynek zagraniczny charakteryzuje się wysokim ryzykiem i niską atrakcyjnością². Można mieć do czynienia z sytuacją, w której przedsiębiorstwo nie wybiera jednego rynku, lecz spośród kilkunastu ocenianych rynków zagranicznych wybiera kilka. Wynika to przede wszystkim z zasobów finansowych i kadrowych przedsiębiorstwa.

Po dokonaniu wyboru rynku zagranicznego przedsiębiorstwo powinno ustalić sposób wejścia na ten rynek. Zgodnie ze wspomnianą wyżej koncepcją opracowaną przez naukowców Uniwersytetu w Uppsali, mamy do czynienia z kilkoma formami ekspansji na rynki zagraniczne ${ }^{3}$. Możemy tu ze względu na zaangażowanie kapitałowe przedsiębiorstwa wymienić następujące formy:

- działania eksportowe oraz handel wymienny,

- kooperacja niekapitałowa z partnerem zagranicznym,

${ }^{1}$ W. Grzegorczyk, Marketing na rynku międzynarodowym, Wolters Kluwer, Warszawa 2013, s. $50-57$.

2 J. Bruns, Internationales Marketing, F. Kiehl Verlag, Ludwigshafen 2003, s. 82-85.

3 W. Keegan, B. Schlegelmilch, B. Stoettinger, Globales Marketing-Management, R. Oldenbourg Verlag, München-Wien 2002, s. 288-292. 
- kooperacja kapitałowa z partnerem zagranicznym,

- inwestycje bezpośrednie na rynku zagranicznym.

Działania eksportowe są najprostszą i najczęściej występującą formą wejścia przez przedsiębiorstwa na międzynarodowe rynki. Na tym etapie internacjonalizacji spotykamy się także z tzw. obrotem uszlachetniającym, handlem tranzytowym i handlem wymiennym.

Kooperacja niekapitałowa z partnerami z rynków zagranicznych polega na tym, że obie strony nie tworzą wspólnych przedsięwzięć i nie łączą w tym celu kapitałów. Wśród form stosowanych na tym etapie internacjonalizacji wymienia się przekazanie licencji, tworzenie łańcuchów franchisingowych, kontrakty na zarządzanie i inwestycje kompleksowe. Jednak najczęściej wykorzystywane jest przy ekspansji na rynki zagraniczne przekazywanie licencji i franchising.

Kooperacja kapitałowa $\mathrm{z}$ partnerem zagranicznym polega na tworzeniu wspólnych przedsięwzięć i na wspólnym angażowaniu kapitałów. Tworzone są więc tzw. wspólne przedsiębiorstwa (joint ventures), a odmianą takiej kooperacji są alianse strategiczne, czyli porozumienia z partnerami zagranicznymi o wspólnych działaniach dla osiągnięcia grupowej przewagi konkurencyjnej. Najczęstszą formą są joint ventures o charakterze produkcyjnym bądź handlowo-produkcyjnym. Alianse strategiczne z reguły są wykorzystywane przez duże bądź wielkie przedsiębiorstwa. Ostatnia forma wejścia na rynki międzynarodowe to inwestycje bezpośrednie, które polegają na tworzeniu na rynkach zagranicznych własnych oddziałów handlowych, usługowych lub produkcyjnych. Można to osiągnąc budując je od podstaw (green investment) albo przejmując istniejące na rynku zagranicznym przedsiębiorstwa lokalne (brown investment). Ta forma ekspansji wymaga dużych nakładów kapitałowych i znacznego zaangażowania własnego personelu na rynkach zagranicznych.

Podsumowując zaprezentowany wyżej krótko model ekspansji przedsiębiorstwa na rynki zagraniczne, można stwierdzić, że z reguły na początku swojego zaangażowania na tych rynkach przedsiębiorstwo wykorzystuje najprostszą formę - tj. eksport pośredni, a następnie bezpośredni. Są to formy, które nie wymagają dużych nakładów kapitałowych, personalnych, doświadczenia i wiedzy o rynkach międzynarodowych, a ponadto istotnie ograniczają ryzyko niepowodzenia eksportera. W miarę zdobywania doświadczenia przez przedsiębiorstwo, a także przy uwzględnieniu przez nie poziomu atrakcyjności poszczególnych rynków zagranicznych, może ono przechodzić do kolejnych form ekspansji. Po kilku latach przedsiębiorstwo z reguły podejmuje na rynkach zagranicznych inwestycje bezpośrednie, najczęściej tworząc własne zakłady. Wówczas zakres inwestowania uzależniony jest od możliwości kapitałowych przedsiębiorstwa. 
Jak już podkreślono, przeciwieństwem koncepcji fazowej ekspansji przedsiębiorstwa na rynki zagraniczne jest koncepcja jego obecności na tych rynkach od momentu powstania przedsiębiorstwa. Bez wątpienia mamy do czynienia $\mathrm{z}$ takimi przedsiębiorstwami, które funkcjonują od razu na globalnym rynku światowym (firmy typu born global). Odnosi się to jednak przede wszystkim do nowoczesnych sektorów gospodarki, takich jak elektronika, technologie informatyczne, telekomunikacja. $Z$ tego względu nadal przewagę w praktycznej działalności przedsiębiorstw ma fazowy model internacjonalizacji oraz model polegający na pomijaniu niektórych faz i przechodzeniu po fazie wstępnej (np. po eksporcie pośrednim) do fazy rozwiniętej (np. kooperacji kapitałowej lub inwestycji bezpośrednich).

Jak stwierdzono, po ustaleniu formy wejścia na rynki zagraniczne przedsiębiorstwo powinno opracować treść strategii funkcjonalnych, w tym strategii marketingu-mix, jaką zamierza na tych rynkach realizować. Może ona przyjąć formę globalnej strategii marketingu-mix, krajowej strategii lub hybrydowej strategii marketingu-mix.

Strategia globalna jest konsekwencją standaryzacji i polega na stosowaniu na wszystkich rynkach zagranicznych identycznych instrumentów marketingowych i identycznej ich kompozycji. Zakłada się, że mamy do czynienia tzw. klientem globalnym o podobnych potrzebach i preferencjach oraz z podobnymi warunkami ekonomicznymi, kulturowymi, technologicznymi itp. na wszystkich rynkach zagranicznych.

Strategia krajowa natomiast jest konsekwencją adaptacji i założenia odrębności i specyfiki każdego rynku zagranicznego. Dla każdego z nich przygotowuje się i realizuje odrębną strategię marketingu-mix, skonstruowaną na podstawie cech specyficznych każdego rynku.

Z kolei strategia hybrydowa łączy działania standaryzacyjne i adaptacyjne. Polega ona na standaryzowaniu większości instrumentów marketingu-mix i adaptowaniu pozostałych do specyfiki rynków zagranicznych. Na przykład jednolity może być produkt i działania promocyjne, ale dostosowana do specyfiki kraju strategia dystrybucji i poziom ceny produktu lub jednolity produkt, podobna cena i dystrybucja, ale zmieniona polityka promocji.

\section{Formy wejścia na rynki zagraniczne polskich przedsiębiorstw}

Udział polskich przedsiębiorstw w procesach internacjonalizacyjnych jest nadal raczej niewielki. Główne formy ekspansji na rynki zagraniczne to eksport oraz obrót uszlachetniający. Jest to najczęściej eksport pośredni i tylko niewiele pol- 
skich przedsiębiorstw dociera ze swoimi produktami do ostatniego ogniwa w kanałach dystrybucji. Wykorzystanie eksportu jako najważniejszej formy ekspansji na rynki międzynarodowe wynika głównie ze stosunkowo nieskomplikowanego procesu transakcji eksportowych i niskiego ryzyka. W ciągu kilku ostatnich lat odnotowano bardzo szybki przyrost wartości polskiego eksportu. W roku 2004 jego wartość osiągnęła ok. 60 mld euro, w 2006 roku ok. 88 mld euro, w 2008 roku ok. 116,5 mld euro. W roku 2009, ze względu na światowy kryzys gospodarczy, odnotowano spadek eksportu do poziomu ok. 99 mld euro, ale w 2010 roku przekroczył on już 120 mld euro, a w 2012 ponad 153,4 mld euro ${ }^{4}$. Według szacunków w 2013 roku eksport osiągnie ponad 158,3 mld euro, a w 2014 173,6 mld euro. Po pierwszej połowie 2013 roku po raz pierwszy od 10 lat osiągnięty został dodatni bilans w handlu zagranicznym na kwotę ponad 1 mld euro ${ }^{5}$. Gdyby za 100 przyjąć wartość eksportu z 2004 roku, to w 2006 roku wynosił on ok. 147, w 2008 ok. 194, w 2009 roku nastąpił spadek do poziomu 165, w 2010 roku było to ok. 200, a w 2012 roku -256. Widać więc, że w ciągu ośmiu lat wartość eksportu wzrosła o ponad 156\%.

Skutkiem wzrostu wartości eksportu były także zmiany w udziale Polski w eksporcie światowym i europejskim. Udział Polski w eksporcie światowym w 1995 roku wynosił 0,5\%, w 2004 roku ok. 0,9\%, a w 2012 roku 1,0\%. Natomiast udział w eksporcie Europy wynosił w tych latach odpowiednio 1, 1,7 i $2,8 \% \%^{6}$. Wartość eksportu na jednego mieszkańca na świecie w 2010 roku wyniosła ponad 2208 dolarów, a w Polsce 4065 dolarów. W 2012 roku wartość eksportu na jednego mieszkańca świata wyniosła ponad 2,6 tys. dolarów, a w Polsce wzrosła do ok. 5100 dolarów. W 1990 roku Polska była pod tym względem na 91 miejscu na świecie, a w 2010 roku na miejscu 63. Wielkości te były zbliżone do wskaźników dla Hiszpanii i Portugalii†. Korzystnie zmieniała się także struktura eksportu - np. w 2005 roku maszyny, urządzenia i sprzęt transportowy stanowiły w eksporcie ok. 39,6\%, w 2009 roku ponad 43,9\%, a w 2011 roku ponad $44 \%$, natomiast udział produktów wysokich technologii w eksporcie wzrósł z 4 do 5\%. Jest to jednak nadal bardzo skromny wkład tej grupy produktów w całości eksportu. Zmniejszył się z kolei udział surowców mineralnych i drewna

${ }^{4}$ Rocznik statystyczny, GUS, Warszawa 2007, s. 737-738; Rocznik statystyczny handlu zagranicznego, GUS, Warszawa 2010, s. 38 oraz Raport o stanie handlu zagranicznego w 2012 roku, Ministerstwo Gospodarki, Warszawa 2013, www. mg.gov.pl/file/upload 8437 [dostęp: 20.04.2013].

${ }^{5}$ A. Woźniak, Mocno rośnie eksport na Wschód, „Rzeczpospolita”, 13.08.2013.

${ }^{6}$ Rocznik Statystyczny RP, GUS, Warszawa 2006; s. 737-738, Rocznik statystyki międzynarodowej, GUS, Warszawa 2009, s. 40-42 oraz Raport o stanie handlu...

7 M. Gorynia, Eksport szansa Polski, „Rzeczpospolita”, 13.07.2012 oraz Handel globalny w 2012 roku i prognozy na 2013 rok, Ministerstwo Gospodarki, Warszawa 2013, www.mg.gov.pl. 
w eksporcie z 12,5 do 8,6\% ${ }^{8}$. Zdecydowana większość eksportu przypadała na kraje rozwinięte - w 2005 roku ponad 83,5\%, a w 2011 roku ok. 84\%. Spadł natomiast udział krajów rozwijających się, $\mathrm{z}$ ok. $7 \% \mathrm{w}$ roku 2005 do ponad $6,2 \%$ w 2011 roku. Główne rynki eksportowe to Niemcy, Włochy, Francja, Wielka Brytania i Czechy. Trzeba podkreślić, że przedsiębiorstwa eksportujące charakteryzują się wysokim poziomem rentowności (od 7,3\% nawet do10\%), wyższym o ponad trzy punkty procentowe od rentowności przedsiębiorstw nie eksportujących ${ }^{9}$. Wśród ogółu polskich firm ok. 77\% przedsiębiorstw było rentownych, natomiast wśród firm eksportujących wskaźnik ten wynosi ponad $81 \%$. Mimo tych pozytywnych tendencji i wyjątkowo dynamicznego wzrostu eksportu stwierdzić należy, że tendencja ta odnosi się głównie do dużych i średnich przedsiębiorstw. Eksportem zajmowały się przede wszystkim przedsiębiorstwa zatrudniające ponad 9 osób. W 2008 roku liczba takich przedsiębiorstw wynosiła 46,5 tys. i stanowiły one ok. 3\% ogółu przedsiębiorstw w Polsce. Z tej liczby ok. jedna trzecia - tj. 14,9 tys. prowadziła eksport. W 2009 roku liczba przedsiębiorstw zatrudniających ponad 9 osób wzrosła do 74,3 tys., z czego ponad 17 tys. to eksporterzy. Ich udział w ogólnej liczbie przedsiębiorstw nie przekraczał jednak $1 \%{ }^{10}$. W 2010 roku liczba eksporterów o zatrudnieniu ponad 9 osób zmniejszyła się do ok. 14 tys., a ich udział w ogólnej liczbie przedsiębiorstw $(1,673 \mathrm{mln})$ spadł do ok. $0,9 \%{ }^{11}$.

Niezwykle rzadko spotykamy się z kolejnymi po eksporcie formami wejścia na rynki międzynarodowe - tj. kooperacją kapitałową i niekapitałową. Sprzedaż licencji czy tworzenie łańcucha franchisingowego przez polskie przedsiębiorstwa na rynkach zagranicznych są niezwykle sporadyczne. Do takich pozytywnych przykładów można zaliczyć firmy z branży odzieżowej i kosmetycznej - np. LPP, Kan, Redan, CCC, Dr Irena Eris. Wynika to głównie z faktu, że polskie przedsiębiorstwa nie dysponują ofertą, która umożliwiałaby szerokie wykorzystanie niekapitałowych form wejścia na rynki zagraniczne. Podobnie powoływanie spółek joint ventures czy tworzenie aliansów strategicznych należy do absolutnej rzadkości.

Natomiast spotkać się można coraz częściej z inwestycjami bezpośrednimi polskich firm za granicą, w postaci wykupu istniejących przedsiębiorstw lub tworzenia własnych oddziałów od podstaw. Wielkość polskich inwestycji bezpośrednich za granicą jest jednak nadal niewielka, choć wykazuje tendencję rosnącą. $\mathrm{Na}$ koniec 2004 roku inwestycje te wynosiły ok. 2,36 mld euro i był to wzrost w po-

\footnotetext{
${ }^{8}$ Rocznik statystyczny handlu zagranicznego, GUS, Warszawa 2010, s. 394-398.

9 D. Jałowiecki, Kierunki i tendencje rozwoju eksportu, http://www.rig.katowice.pl [dostęp: 25.10.2010] oraz GUS Rocznik statystyczny handlu..., s. 38.

${ }^{10}$ Kryzys finansowy a handel zagraniczny, Biuro Analiz Sejmowych, Wydawnictwo Sejmu, Warszawa 2010, s. 37-50.

${ }^{11}$ Raport o stanie matych i średnich przedsiębiorstw w Polsce, PARP, Warszawa 2011, s. 32.
} 
równaniu do roku poprzedniego o ponad 38\%. W 2006 roku można było odnotować kolejny wzrost polskich inwestycji bezpośrednich za granicą do kwoty 9,6 mld euro, w 2008 roku osiągnęły kwotę ok. 17,1 mld euro, a w 2009 roku kwotę 20,3 mld euro. W 2010 roku wartość polskich inwestycji bezpośrednich za granicą wzrosła do 33,3 mld euro, a w 2011 roku do kwoty 38,4 mld euro ${ }^{12}$. Natomiast zagraniczne inwestycje bezpośrednie w Polsce przekroczyły w 2011 roku kwotę $160 \mathrm{mld}$ euro $^{13}$. Inwestycje zagraniczne polskich przedsiębiorstw skoncentrowane są w Europie - trafia tam ponad $90 \% \mathrm{z}$ nich, w tym na Europę Zachodnią przypada ok. $70 \%$ inwestycji, a na Europę Środkowowschodnią ok. 21\%. Największe rynki polskich inwestycji bezpośrednich to Niemcy, Czechy, Litwa, Słowacja, Ukraina, Węgry i Rumunia. Szacuje się, że w Niemczech wartość polskich inwestycji bezpośrednich przekroczyła kwotę $600 \mathrm{mln}$ euro, a do rejestru działalności gospodarczej wpisanych zostało ponad 20 tys. polskich przedsiębiorstw. W Norwegii inwestycje wyniosły prawie $390 \mathrm{mln}$ euro, a we Francji ok. $310 \mathrm{mln}$ euro ${ }^{14}$. Do największych inwestorów zalicza się PKN Orlen, Unimil SA, Boryszew SA, Selena SA, polskie firmy odzieżowe (LPP, Redan, Kan). W Czechach wartość polskich inwestycji bezpośrednich przekroczyła $500 \mathrm{mln}$ euro, na tym rynku do największych inwestorów zaliczyć można PKN Orlen, Maspex Mokate, LPP, Tatuum, CCC i firmy z branży meblarskiej (VOX, Kler, Forte). Poważne kwoty inwestycji bezpośrednich polskich firm odnotować można także na Litwie (PKN Orlen 3,5 mld euro), w Rumunii i na Ukrainie (Can-Pack ok. $35 \mathrm{mln}$ euro i Forte ok. $10 \mathrm{mln}$ euro). Na Węgrzech i w Bułgarii polskim liderem inwestycji bezpośrednich jest Maspex, który wykupił producenta napojów owocowych.

Podsumowując można stwierdzić, że polskie przedsiębiorstwa z powodu ograniczeń kapitałowych i relatywnie małego doświadczenia w zakresie postępowania na rynkach zagranicznych wybierały proste i mało ryzykowne formy ekspansji na nie. Ponadto ich działanie było zgodne z modelem internacjonalizacji Uniwersytetu w Uppsali. Firmy decydowały się na wybór jednego rynku zagranicznego, a następnie w miarę zdobywania wiedzy wchodziły na kolejne rynki zagraniczne.

${ }^{12}$ Polskie inwestycje bezpośrednie za granica w 2011 roku, Raport Ministerstwa Gospodarki, Warszawa 2013, www.mg.gov.pl/files/upload.84399 [dostęp: 20.04.2013].

13 www.paiz.gov.pl/polska_w_liczbach/inwestycje_zagraniczne.

${ }^{14}$ Ekspansja międzynarodowa polskich przedsiębiorstw produkcyjnych, KPMG i PAI i Z, Warszawa 2010. 


\section{Strategie marketingu-mix polskich przedsiębiorstw na rynkach zagranicznych}

Opracowanie i realizacja strategii marketing-mix to kolejny istotny etap strategii działania przedsiębiorstwa na rynkach zagranicznych. Przygotowanie strategii powinno być jednak poprzedzone badaniami marketingowymi wybranych rynków zagranicznych. Mogą być one realizowane przez wyspecjalizowane firmy badawcze, ale w praktyce nie zdarza się, by wszystkie badania marketingowe były zlecane przez przedsiębiorstwa agencjom badawczym. Część badań rynków zagranicznych, opartych głównie na wtórnych źródłach informacji, może być wykonana własnymi siłami przedsiębiorstwa. Wiąże się to jednak z utworzeniem w jego strukturze komórki organizacyjnej zajmującej się właśnie badaniami marketingowymi. Jednak bardzo często konieczne jest wykonanie badań pierwotnych rynków międzynarodowych i wówczas, ze względu na ich złożoność i wysoki stopień skomplikowania, należy je powierzać wyspecjalizowanym agencjom badawczym. Obydwie wspomniane sytuacje powodują poniesienie przez przedsiębiorstwo dodatkowych nakładów finansowych. W praktyce właśnie z tego powodu badania marketingowe są relatywnie skromne, choć można zauważyć tendencję do wzrostu wydatków przedsiębiorstw na te cele. W 2003 roku nakłady na badania marketingowe przedsiębiorstw w Polsce wyniosły ok. 100 mln dol., w 2006 ok. $190 \mathrm{mln}$, w 2007 już ponad $230 \mathrm{mln}$, a w 2010 roku obniżyły się do ponad 220 mln dolarów ${ }^{15}$. Trzeba podkreślić, że nakłady na badania marketingowe rynków zagranicznych ponoszą głównie duże i średnie przedsiębiorstwa, ponieważ to przede wszystkim one dokonują ekspansji na te rynki. Podejmowanie badań marketingowych uzależnione jest od wielkości przedsiębiorstwa. Przedsiębiorstwa małe z reguły nie dysponują niezbędnymi środkami finansowymi umożliwiającymi realizację badań własnych. Najczęściej korzystają z nieskomplikowanych źródeł wtórnych, takich jak np. własna dokumentacja handlowa, opracowania i raporty stowarzyszeń branżowych czy izb handlowych oraz informacje od partnerów biznesowych, a dopiero w drugiej kolejności wykorzystywane są własne badania pierwotne - np. obserwacje lub badania ankietowe ${ }^{16}$. Na zakres i intensywność badań marketingowych wpływają wielkość przedsiębiorstwa, liczba rynków zagranicznych, na których funkcjonują, i czas działania na tych rynkach. Potwier-

${ }^{15}$ Zob. „Gazeta Wyborcza”, 1.04.2008.

${ }^{16}$ A. Żbikowska, Uwarunkowania ekspansji eksportowej polskich przedsiębiorstw, „Marketing i Rynek” 2013, nr 2; M. Barosik-Purgat, H. Mruk, J. Schroeder, Dostepność informacji o rynkach i partnerach zagranicznych $w$ procesie internacjonalizacji polskich przedsiębiorstw, Wyd. UE w Poznaniu, Poznań 2012, s. 59. 
dzają to badania polskich eksporterów, z których wynika, że większość przedsiębiorstw nie prowadziła badań marketingowych $\mathrm{w}$ takim znaczeniu, w jakim są one definiowane w publikacjach marketingu. Im większa firma i im większa liczba obsługiwanych rynków zagranicznych, tym większy odsetek przedsiębiorstw prowadzących badania marketingowe. Większość przedsiębiorstw decydowała się na samodzielne prowadzenie badań marketingowych rynków zagranicznych, korzystając głównie z Internetu oraz oficjalnych statystyk obcych krajów i czasopism fachowych ${ }^{17}$. Badania marketingowe realizowane były głównie przez komórki eksportowe, a w drugiej kolejności tworzone były samodzielne komórki ds. badann ${ }^{18}$.

Strategie marketingowe realizowane przez polskie firmy na rynkach zagranicznych można zaliczyć do strategii selektywnego rozwoju. Często jest to także strategia podwójnej koncentracji, polegająca na wyborze niewielu (lub jednego segmentu rynku) i niewielu (lub jednego) rynku zagranicznego. Takie strategie pozwalają ograniczyć ryzyko i koszty wejścia na nowe rynki. Realizowane przez polskie przedsiębiorstwa na rynkach zagranicznych strategie marketingowe można także zaliczyć do krajowych strategii marketingu-mix. Wynika to z faktu, iż przedsiębiorstwa te nie dysponują dużymi zasobami kapitałowymi i nie są w stanie sfinansować badań marketingowych rozległych rynków zagranicznych ani strategii marketingowych na nich. Natomiast strategie selektywnego rozwoju (koncentracji), polegające na wyborze segmentu rynku (niszy rynku) i osiągnięciu na nim pozycji lidera, nie wymagają dużych nakładów kapitałowych. Niezbędna jest raczej specjalistyczna oferta, którą polskie przedsiębiorstwa dysponują. Ponieważ większość polskich przedsiębiorstw działa na stosunkowo niewielu rynkach i wchodzi na nie systematycznie, to każda $\mathrm{z}$ tych strategii jest dostosowana do specyfiki poszczególnych rynków zagranicznych. Wyniki badań polskich eksporterów pozwalają sformułować wnioski o relatywnie dużej zgodności narzędzi ich konkurowania na rynku krajowym i na rynkach zagranicznych. Oznacza to, że polskie przedsiębiorstwa stosują orientację etnocentryczną. Świadczy o tym także fakt, iż większość $\mathrm{z}$ nich oferuje na rynkach zagranicznych asortyment zbliżony do proponowanego na rynku krajowym. Odnosi się to do małych i średnich eksporterów. Natomiast duże przedsiębiorstwa eksportujące jednocześnie przygotowują i realizują odrębne dla poszczególnych rynków zagranicznych marketingowe plany działania, co świadczy o realizowaniu przez nie policentrycznej orientacji internacjonalizacyjnej. Tylko duże polskie przedsiębiorstwa wykazują orientację regiocentryczną.

\footnotetext{
${ }^{17}$ Ibidem.

${ }^{18}$ M. Bartosik-Purgat, H. Mruk, J. Schroeder, op. cit., s. 83-85.
} 
Można uznać, że polityka produktu polskich firm odpowiada standaryzacji i podejmowaniu adaptacji, czyli dostosowywaniu oferty do wymogów wybranego segmentu rynku. Zdecydowanie korzystniejsza jest polityka standaryzacji, ale ta jest realizowana wówczas, gdy przedsiębiorstwo funkcjonuje na kilku rynkach. W zakresie polityki marki podejmowane są próby (poza branżą spożywczą czy pojedynczymi firmami z branży odzieżowej, kosmetycznej i budowlanej) stosowania polityki własnej oryginalnej marki. Jest to działanie trudne, ponieważ polskie marki nie są znane na rynkach zagranicznych, a w niektórych krajach produkty z Polski nie mają pozytywnego wizerunku. Działania zmierzające w kierunku jego poprawy wymagałyby bardzo dużych nakładów na promocję. Znaczna część polskich przedsiębiorstw dostarcza swoje produkty na rynki zagraniczne pod marką pośrednika w kanale dystrybucji. Nie spotykamy się także (poza niezwykle rzadkimi wyjątkami) z wprowadzaniem na rynki zagraniczne innowacji przez polskie firmy. Asortyment oferowany na rynkach zagranicznych nie odbiega istotnie o oferowanego na rynku krajowym ${ }^{19}$. Najczęściej działania polskich przedsiębiorstw w tym zakresie można zaliczyć do strategii elastycznej specjalizacji. Polega ona na modyfikowaniu produktów tak, by dostosować je do wymagań wybranego segmentu rynku. Częściej jednak realizowana jest strategia zależna, czyli przyjecie przez polskie firmy roli podwykonawcy, który dostarcza robociznę, ewentualnie półprodukty.

Polityka cenowa polskich firm obejmuje najczęściej ustalanie cen na swoje produkty za pomocą metody kosztowej przy jednoczesnym porównaniu tak skalkulowanej ceny z cenami produktów konkurencyjnych. Zdecydowana większość polskich eksporterów ustala ceny eksportowe na innym poziomie niż ceny na te produkty w kraju. Jest to konsekwencja polityki adaptacji do warunków na rynkach zagranicznych ${ }^{20}$. W efekcie prowadzi to do stosowania polityki cenowej średniej wartości lub/i polityki dobrej okazji. Pierwsza z nich odnosi się do nabywców, dla których istotna jest cena na średnim poziomie rynkowym i średnia jakość produktów. Natomiast polityka dobrej okazji cenowej polega na ustaleniu relatywnie niskiej ceny dla produktów o średniej jakości lub średniej ceny dla produktów wysokiej jakości. Jak widać, mamy do czynienia z ustalaniem cen na średnim lub niskim poziomie rynkowym. Jest to ściśle powiązane z polityką marki, ponieważ niezwykle mało polskich przedsiębiorstw dostarcza swoje produkty na rynki zagraniczne pod własną i znaną marką. Dodatkowo, jak wspomniano,

${ }_{19}$ T. Smoleń, Działania polskich eksporterów na rynkach międzynarodowych. Analiza wyników badań, „Marketing i Rynek” 2013, nr 2.

${ }^{20}$ A. Jonas, Strategie obecności polskich przedsiębiorstw na rynkach zagranicznych, „Marketing i Rynek” 2013, nr 2; T. Smoleń, op. cit. 
na wielu rynkach mamy do czynienia z negatywnymi stereotypami odnoszącymi się do polskich produktów i wówczas cena ustalana jest na średnim lub relatywnie niskim poziomie. Mimo stosunkowo niskich cen przedsiębiorstwa eksportujące są rentowne, ponieważ koszty pracy w nich, niezależnie od podwyżek płac w sektorach eksportowych w Polsce, nadal jeszcze stanowią nieznaczny udział w cenie eksportowanych produktów. Rentowności sprzyja także elastyczny kurs złotego do walut zagranicznych (euro i dolara USA). Przedsiębiorstwa eksporterzy, a szczególnie eksporterzy wyspecjalizowani, charakteryzowały się znacznie wyższą rentownością niż przedsiębiorstwa nieeksportujące ${ }^{21}$.

W odniesieniu do polityki dystrybucji przedsiębiorstwa stoją przed kilkoma wyborami:

a) budować własny kanał dystrybucji czy korzystać z kanału obcego;

b) współpracować z pośrednikami niezależnymi przejmującymi ryzyko i koszty sprzedaży produktu czy też

c) wykorzystywać pośredników działających na cudzy rachunek i w cudzym imieniu.

Polityka dystrybucji polskich firm za granicą polega na wykorzystywaniu przez nie obcych kanałów dystrybucji. Tylko niektóre przedsiębiorstwa decydowały się na tworzenie własnych kanałów lub tworzenie sieci franchisingowej. Wynika to z dużych kosztów budowy własnego kanału dystrybucji, często z też braku personelu, który byłby w stanie efektywnie zarządzać takimi kanałami. Polskie przedsiębiorstwa preferują także niezależnych pośredników w kanałach dystrybucji, ponieważ, jak już podkreślono, są oni w stanie przejąć ryzyko i koszty sprzedaży produktów na zagranicznych rynkach. Kanały dystrybucji wykorzystywane przez zdecydowaną większość polskich przedsiębiorstw na rynkach zagranicznych różnią się istotnie od tychże kanałów stosowanych w kraju ${ }^{22}$. Oznacza to, że dystrybucja jest kolejnym elementem strategii adaptacji polskich eksporterów do specyfiki rynków zagranicznych.

Polityka promocji na rynkach zagranicznych może przyjąć formę działań jednolitych lub zróżnicowanych i jest ona trudna i kosztowna w realizacji. Wymaga bowiem bardzo dobrej znajomości rynku usług promocyjnych za granicą, a także stopnia wrażliwości nabywców zagranicznych na środki przekazu promocyjnego. W związku z tym, najczęściej polskie przedsiębiorstwa przenoszą działania promocyjne na pośredników w kanale dystrybucji, a te, które podjęły inwestycje bezpośrednie na zagranicznych rynkach, zlecają miejscowym agencjom

${ }^{21}$ D. Ciesielska, Uwarunkowania zewnętrzne handlu zagranicznego w okresie kryzysu finansowego i ich wplyw na rentowność polskich eksporterów, „Handel Wewnętrzny” 2012, nr 5.

${ }^{22}$ T. Smolen, op. cit. 
promocyjnych przygotowanie działan promocyjnych. Treść i forma przekazów promocyjnych odnoszących się do produktów polskich eksporterów na rynkach zagranicznych jest $\mathrm{w}$ zdecydowanej większości odmienna od treści przekazu na polskim rynku. Odmienne są także narzędzia polityki promocji-mix, jakie wykorzystywane są na rynkach zagranicznych ${ }^{23}$. Świadczy to, podobnie jak w odniesieniu do polityki dystrybucji, o stosowaniu strategii różnicowania promocji i działaniach adaptacyjnych do specyfiki rynków zagranicznych.

\section{Zakończenie}

Polskie przedsiębiorstwa wykorzystują do ekspansji na rynki międzynarodowe przede wszystkim eksport $\mathrm{w}$ formie pośredniej. Pozostałe sposoby ekspansji na te rynki stosowane są w bardzo niewielkim zakresie. Realizują one także na nich relatywnie nieskomplikowane strategie marketingu-mix. Konkurowanie na zagranicznych rynkach odbywa się głównie za pomocą produktów dostosowanych do potrzeb lokalnych nabywców, rzadko oznakowanych marką producenta, najczęściej marką pośrednika w kanale dystrybucji. Są to produkty o średniej lub dobrej jakości i średnich, ewentualnie niskich cenach w stosunku do cen konkurencyjnych produktów. Polskie przedsiębiorstwa rzadko podejmują samodzielnie działania promocyjne, za które najczęściej odpowiadają zagraniczni pośrednicy w kanale dystrybucji. Nie budują także na rynkach zagranicznych własnych kanałów dystrybucji, służących nawet tylko jako uzupełnienie obcych kanałów. Można stwierdzić, że strategie marketingu-mix polskich przedsiębiorstw na rynkach międzynarodowych były przygotowane i realizowane prawidłowo. Zastosowane narzędzia marketingu-mix odpowiadały ich zasobom finansowym, personalnym, ofercie, wiedzy o rynkach zagranicznych, doświadczeniu i umiejętnościom funkcjonowania na nich. Takie strategie przynosiły do tej pory pozytywne rezultaty. Widać było bowiem systematyczne i silne przyrosty eksportu, korzystną zmianę struktury eksportu - tj. wzrost obrotów wyżej przetworzonych produktów i wzrost efektywności ekonomicznej eksporterów. W efekcie pozwalało to polskim eksporterom umacniać swoją pozycję zarówno na krajowym rynku, jak i na rynkach zagranicznych. Wydaje się jednak, że w dłuższym okresie działania marketingowe powinny zostać zmodyfikowane, szczególnie w kierunku wykreowania na rynkach zagranicznych własnych oryginalnych marek i dodatkowych własnych kanałów dystrybucji.

${ }^{23}$ Ibidem. 


\section{Bibliografia}

Bartosik-Purgat M., Mruk H., Schroder J., Dostępność i wykorzystanie informacji o rynkach i partnerach zagranicznych w procesie internacjonalizacji polskich przedsiębiorstw, Wyd. UE w Poznaniu, Poznan 2012

Bruns J., Internationales Marketing, F. Kiehl Verlag, Ludwigshafen 2003

Ciesielska D., Uwarunkowania zewnętrzne handlu zagranicznego w okresie kryzysu finansowego i ich wptyw na rentowność polskich eksporterów, „Handel Wewnętrzny" 2012, nr 5

Ekspansja międzynarodowa polskich przedsiębiorstw produkcyjnych, KPMG

i PAI i Z, Warszawa 2010

Gorynia M., Eksport szansa Polski, „Rzeczpospolita”, 13.07.2012

Grzegorczyk W., Marketing na rynku międzynarodowym, Oficyna Wolters Kluwer, Warszawa 2013

Handel globalny w 2012 roku i prognozy na 2013 rok, Ministerstwo Gospodarki,

Warszawa 12.04.2013, www.mg.gov.pl

Jałowiecki D., Kierunki i tendencje rozwoju eksportu, http://www.rig.katowice.pl Jonas A., Strategie obecności polskich przedsiębiorstw na rynkach zagranicznych,

„Marketing i Rynek” 2013, nr 2

Keegan W., Schlegelemilch B., Stoettinger B., Globales Marketing-Management,

Oldenbourg R. Verlag, München-Wien 2002

Kryzys finansowy a handel zagraniczny, Biuro Analiz Sejmowych, Wydawnictwo

Sejmu, Warszawa 2010

Maciejewicz P., Wzrost płac nie szkodzi zyskom, „Gazeta Wyborcza”, 21.11.2007

Polskie inwestycje bezpośrednie za granica w 2008 roku, NBP, Warszawa, grudzień 2009, http://www.nbp.pl/publikacje/pib/pib.html

Polskie inwestycje bezpośrednie za granica w 2009 roku. Aneks Statystyczny. NBP, Warszawa, wrzesień 2010, http://www.nbp.pl/publikacje/pib./pib.html Polskie inwestycje bezpośrednie za granica w 2011 roku. Raport Ministerstwa Gospodarki, Warszawa 2013, http//www.mg.gov.pl/files/upload.84399

Raport o stanie handlu zagranicznego w 2012 roku, Ministerstwo Gospodarki,

Warszawa 2013, http//www.mg.gov.pl/file/upload 8437

Raport o stanie matych $i$ średnich przedsiębiorstw $w$ Polsce, PARP, Warszawa 2011

Rocznik statystyczny, GUS, Warszawa 2007

Rocznik statystyczny handlu zagranicznego, GUS, Warszawa 2010

Rocznik statystyczny RP, GUS Warszawa 2006 
Rocznik statystyki międzynarodowej, GUS, Warszawa 2009

Smoleń T., Działania polskich eksporterów na rynkach międzynarodowych. Analiza wyników badań, „Marketing i Rynek” 2013, nr 2

Woźniak A., Mocno rośnie eksport na Wschód, „Rzeczpospolita”, 13.08.2013

Żbikowska A., Uwarunkowania ekspansji eksportowej polskich przedsiębiorstw, „Marketing i Rynek” 2013, nr 2 